\title{
Rural farmers' perceptions, knowledge and management of insect pests of fruit vegetables in Ogbomoso Agricultural Zone of Nigeria
}

\author{
Oladele Abiodun Olaniran ${ }^{1}$, Samuel Adelani Babarinde ${ }^{1, *}$, \\ Adeola Foluke Odewole ${ }^{1}$, Peter Ademola Aremu ${ }^{2}$, Kehinde Popoola ${ }^{1}$ \\ ${ }^{1}$ Department of Crop and Environmental Protection, Ladoke Akintola University of Technology, \\ P. M .B. 4000, Ogbomoso, 210001, Nigeria \\ ${ }^{*} \mathrm{Tel}+2348054765393$ \\ ${ }^{2}$ Outreach Department, National Cereals Research Institute, Baddegi, Niger State, Nigeria \\ *E-mail address: sababarinde@lautech.edu.ng , samdelani@yahoo.com
}

\begin{abstract}
Surveys were carried out in five local government areas of Ogbomoso Agricultural Zone Nigeria during planting season in 2010 to investigate rural farmers perceptions and management practices of insect pests of fruit vegetables. The survey involved 150 randomly selected farmers who were interviewed using structured questionnaire. Fruit vegetables planted by the farmers were okra, tomatoes, pepper and garden egg. Reasons given by farmers for cultivating fruit vegetables were significantly favored by age category, educational qualification, and secondary occupation of farmers $\left(\mathrm{x}^{2}=4.757, \mathrm{P}=0.029\right)$. Field insect pests were perceived as the major production constraint to fruit vegetables in this zone. Majority of the farmer estimated $78.4 \%$ rated insect pest as the most serious pest infesting fruit vegetables, the insect pests were grasshopper (Orthoptera), beetles (Coleoptera) and caterpillar (Lepidoptera). Integrated pest management module consisted basically of chemical and cultural control strategies, with weeding, shifting cultivation and crop rotation as main cultural control methods. More than $76.7 \%$ of the farmers make use of cultural control because of unavailability and cost of chemical insecticides. Only $23.3 \%$ had access to chemical insecticides in controlling insect pest of fruit vegetables.
\end{abstract}

Keywords: Farmer's knowledge; fruit vegetables; caterpillar; beetles; grasshoppers; cultural control Ogbomoso agricultural zone; insect pest management

\section{INTRODUCTION}

Fruit vegetable is an important part of the world agriculture and its production is amongst the most important in vegetable production. Fruit vegetables such as tomato (Lycopersicum Lycopersicum), garden egg (Solanum arethiopicum), okra (Abelmoschus escluentus), onion (Alium cepa), water melon (Citrullus lanatu) are found in tropical, subtropical and warm temperate regions. Despite the importance of these crops, there are various constraints to their production which includes high cost of input, transportation, 
accessibility to market, insect pest infestation and disease problems. Most farmers, especially the small scale farmers who grow vegetables year round using both rain-fed and irrigation water, identified insect pest infestation as a major constraints to their production (Ojo et al., 1997). Arthropods are the main pest of fruit vegetables some of which are caterpillars/moth, grasshopper and beetles. Shamser et al. (1976) reported that the attack by various insect pests attack the foliate, stems, buds, flowers, fruits and seeds resulting in substantial crop losses of marketable yield.

Rural farmers in the area of study produce vegetables on a small scale and usually small scale producers are resource - poor and consequently risk aversive. On a general note, farmers have various forms of indigenous knowledge to solve pest problems of fruit vegetables which are generally adapted to the existing economic, social and climatic conditions. Such indigenous knowledge form the concept of Cultural control: which includes Shifting cultivation, crop rotation, field hygiene and manipulation of planting period. In Africa, the majority of farmers still depend on indigenous pest management approaches to manage pest problem (Abate et al., 2000).

An understanding of farmers indigenous knowledge and the strategies they adopt in solving problems helps in conducting research which involves farmers' participation and that will lead to adoptable and effective pest control option which meet farmers' needs (Ampofo, 1997; Nyeko et al., 2002; Tefera, 2004). Also, farmer current perceptions of pests insect control practices and available resources for control may provide essential data for the successful development of pest management strategy and also contribute for rural development (Gabriel, 1989).

To develop integrated and sustainable pest management strategies in fruit vegetable cropping system it is highly necessary to have adequate information about farmer's participatory pest management strategies. Therefore the aim of this study is to investigate the farmers' perceptions, knowledge and insect pest management practices on cultivation of fruit vegetables in Ogbomoso, Agricultural zone Nigeria. This will help to assess any gap in the small scale producer system in order to enable the provision of information necessary to promote development of control strategies in the fruit vegetable ecosystem.

\section{MATERIALS AND METHODS}

A total of 150 farmers were interviewed individually in the five local government (LGA) areas of Ogbomoso Agricultural Zone (Ogbomoso south, Ogbomoso North, OgoOluwa, Oriire, and Surulere L.G.A) Nigeria between March 2010 and November 2010. Interviews were conducted using structured questionnaires. To minimize bias questions were interactive and farmers were allowed to indicate other answers in case the stated options did not meet their response(s). Basic information on social economic status, which includes farmers' age, educational level, gender, religion, and marital status were collected. Information was also collected on type of crops grown, crop constrains and farmers knowledge and perception of pests and adopted control methods. Data collected were summarized using frequencies, percentages and chi-square tests for tests of hypotheses. 


\section{RESULTS}

\section{1. Socio - Economic Characteristics of surveyed farmers}

Out of 150 respondents involved in the study for social economic background, $11.3 \% \mathrm{o}$ were from Ogbomoso North, 19.3\% from Ogbomoso South, 13.3\% from Ogo-Oluwa, 48.0\% from Oriire, and $8.0 \%$ from Surulere LGA. The majority $55.3 \%$ were male while $44.7 \%$ were female. Majority of the farmers $60.7 \%$ were single while $34.0 \%$ were married. Also larger percentage $71.3 \%$ of the farmers had secondary education (Table 1). The larger percentage of the farmers were between 20 and 50 years old. $48.7 \%$ of them were Christians while $50 \%$ were muslims.

Table 1. Socio economic characteristics of the respondent $(n=150)$.

\begin{tabular}{|c|c|}
\hline Variable & Respondent (\%) \\
\hline Ogbomoso North & $17(11.3)$ \\
\hline Ogbomoso South & $29(19.3)$ \\
\hline Ogo Oluwa & $20(13.3)$ \\
\hline Oriire & $72(48.0)$ \\
\hline Surulere & $17(8.0)$ \\
\hline Means & 3.22 \\
\hline Standard deviation & 1.136 \\
\hline \multicolumn{2}{|l|}{ Age } \\
\hline Below 20 & 16.7 \\
\hline $20-29$ & 16.0 \\
\hline $30-39$ & 24.7 \\
\hline $40-49$ & 25.3 \\
\hline $50-59$ & 16.7 \\
\hline Above 60 & 0.7 \\
\hline Means & 0.55 \\
\hline Standard deviation & 0.499 \\
\hline \multicolumn{2}{|l|}{ Gender } \\
\hline Female & $67(44.7)$ \\
\hline Male & $85(55.3)$ \\
\hline Means & 1.71 \\
\hline Standard deviation & 56.0 \\
\hline \multicolumn{2}{|l|}{ Religion } \\
\hline Christianity & $73(48.7)$ \\
\hline Islamic & $75(50.0)$ \\
\hline Traditional & $2(1.3)$ \\
\hline Means & 2.80 \\
\hline
\end{tabular}




\begin{tabular}{|c|c|}
\hline Standard deviation & 0.685 \\
\hline Marital status & $51(34.0)$ \\
\hline Married & $91(60.7)$ \\
\hline Single & $8(5.3)$ \\
\hline Widowed & 2.80 \\
\hline Means & 0.685 \\
\hline Standard deviation & $11(7.3)$ \\
\hline Educational status & $20(13.3)$ \\
\hline No formal education & $107(71.3)$ \\
\hline Primary school & $12(8.0)$ \\
\hline Secondary school & 0.304 \\
\hline Post secondary & 0.582 \\
\hline Means & \\
\hline Standard deviation & \\
\hline & \\
\hline
\end{tabular}

\section{2. Farmers reasons for cultivating different fruit vegetable}

Age category, educational qualification and secondary occupation significantly $\left(\mathrm{x}^{2}=\right.$ 4.757, $\mathrm{P}=0.029$ ) affected the reasons for cultivating different fruit vegetables by the respondents. Among the age group, nearly all the farmers planted fruit vegetable. Majority who planted vegetable because it matures early (29.0\%), were aged 30-39 yrs, majority (28.6\%) who planted due to easiness of planting were also 30-39 yrs old. The secondary leavers were the majority who planted due to easiness of planting $(42.9 \%)$, low cost of production $(66.7 \%)$ and easiness to market $(78.3 \%)$. Students were the majority (66.7) that planted fruit vegetable due to low cost of production (Table 3). Farmers were further asked of the type of vegetables they cultivate. A large percentage $34.2 \%$ cultivated tomatoes which was consumed largely in the society, $29.5 \%$ planted Okro, $20.8 \%$ of the farmers planted garden egg and $15.4 \%$ plant peper. Civil servants and farmers with no formal education and above 60 yrs old did not plant vegetables as others do (Table 2).

Table 2. Fruit vegetables planted by farmers.

\begin{tabular}{|c|c|c|c|c|}
\hline \multirow{2}{*}{ Farmer's category } & \multicolumn{3}{|c|}{ Diversity of crop cultivated } \\
\cline { 2 - 5 } & okro & tomato & Peper & $\begin{array}{c}\text { garden } \\
\text { egg }\end{array}$ \\
\hline Age & & & & \\
\hline Below 20 & $3(8.6)$ & $13(21.3)$ & $3(13.0)$ & $6(19.4)$ \\
$20-29$ & $6(17.1)$ & $7(11.5)$ & $7(30.4)$ & $4(12.9)$ \\
$30-39$ & $15(42.9)$ & $12(19.7)$ & $1(4.3)$ & $9(29.0)$ \\
$40-49$ & $6(17.1)$ & $17(27.9)$ & $8(34.8)$ & $7(22.6)$ \\
$50-59$ & $5(14.3)$ & $11(18.0)$ & $4(17.4)$ & $5(16.1)$ \\
\hline
\end{tabular}




\begin{tabular}{|c|c|c|c|c|}
\hline Above 60 & $0(0)$ & $1(1.6)$ & $0(0)$ & \\
Linear by linear association & $0.076(\mathrm{P}=0.782)$ & & & \\
Educational qualification & & & & \\
No formal education & & & & \\
Primary school & $0(0)$ & $1(11.5)$ & $3(13.0)$ & $1(3.2)$ \\
Secondary school & $7(20.0)$ & $4(6.6)$ & $1(4.3)$ & $8(25.8)$ \\
Post secondary & $24(68.6)$ & $45(73.8)$ & $18(78.3)$ & $20(64.5)$ \\
Linear by linear association & $4(11.4)$ & $5(8.2)$ & $1(4.3)$ & $2(6.5)$ \\
& $0.949(\mathrm{P}=0.330)$ & & & \\
Secondary occupation & & & & \\
Civil servant & $0(0)$ & $2(3.3)$ & $0(0)$ & $2(6.5)$ \\
Private business & $4(11.1)$ & $5(8.2)$ & $2(8.7)$ & $8(25.8)$ \\
Student & $20(57.1)$ & $35(57.4)$ & $8(34.8)$ & $13(41.9)$ \\
Retiree & $1(2.9)$ & $6(9.8)$ & $7(30.4)$ & $4(12.9)$ \\
Clergyman & $10(28.6)$ & $13(21.3)$ & $6(26.1)$ & $4(12.1)$ \\
Linear by linear association & $1.386(\mathrm{P}=0.239)$ & & & \\
\hline
\end{tabular}

Table 3. Farmers reasons for cultivating fruit vegetables.

\begin{tabular}{|c|c|c|c|c|}
\hline \multirow[b]{2}{*}{ Farmer's category } & \multicolumn{4}{|c|}{ Reasons for cultivating fruit vegetables } \\
\hline & Easy to plant & $\begin{array}{l}\text { Low cost of } \\
\text { production }\end{array}$ & $\begin{array}{l}\text { Easy to } \\
\text { market }\end{array}$ & $\begin{array}{c}\text { Early } \\
\text { maturity } \\
\text { period }\end{array}$ \\
\hline \multicolumn{5}{|l|}{ Age } \\
\hline Below 20 & $1(14.3)$ & $4(16.7)$ & $3(13.0)$ & $13(16.3)$ \\
\hline $20-29$ & $0(0)$ & $5(20.8)$ & $7(30.4)$ & $10(12.5)$ \\
\hline $30-39$ & $2(28.6)$ & $2(8.3)$ & $1(4.3)$ & $9(29.0)$ \\
\hline $40-49$ & $1(14.3)$ & $7(29.2)$ & $8(34.8)$ & $7(22.6)$ \\
\hline $50-59$ & $2(28.5)$ & $6(25.0)$ & $4(17.4)$ & $5(16.1)$ \\
\hline Above 60 & $1(14.3)$ & $0(0)$ & $0(0)$ & $0(0)$ \\
\hline \multicolumn{5}{|l|}{ Educational qualification } \\
\hline No formal education & $2(28.6)$ & $6(25.0)$ & $3(13.0)$ & $3(3.8)$ \\
\hline Primary school & $1(14.3)$ & $0(0)$ & $1(4.3)$ & $11(13.8)$ \\
\hline Secondary school & $3(42.9)$ & $16(66.7)$ & $18(78.3)$ & $8(25.8)$ \\
\hline Post secondary & $1(14.3)$ & $2(13.8)$ & $1(4.3)$ & $20(64.5)$ \\
\hline Secondary occupation & & & & \\
\hline Civil servant & $2(28.6)$ & $0(0)$ & $0(0)$ & $2(50.0)$ \\
\hline Private business & $2(28.6)$ & $2(8.3)$ & $2(8.7)$ & $10(26.8)$ \\
\hline
\end{tabular}




\begin{tabular}{|c|c|c|c|c|}
\hline Student & $2(27.6)$ & $16(66.7)$ & $8(34.8)$ & $8(25.8)$ \\
Retiree & $0(0)$ & $3(17.5)$ & $7(30.4)$ & $13(41.9)$ \\
Clergyman & $1(14.3)$ & $3(12.5)$ & $6(26.1)$ & $21(25.0)$ \\
Linear by linear association & $4.757(\mathrm{P}=0.029)$ & & & \\
\hline
\end{tabular}

\section{3. Farmers assessment of insect pest infestation}

Farmers identified various insect pests of fruit vegetables by their common names and gave a list of the pests to include grasshopper, carterpillars and beetles (Table 4) Among these, grasshoppers (67.6\%) was reported as the major pest followed by beetles and butterflies. The majority of those who indicated lack of knowledge on insect pests were aged $40-49$ yrs. Of all the total respondents only $8=12 \%$ lacked knowledge of pests. However, age group had no significant effect on awareness of pest $\left(\mathrm{X}^{2}=0.195, \mathrm{P}=0.659\right)$ on vegetables. Also, farmers education status have no impact on knowledge of insect pest $\left(\mathrm{x}^{2}=\right.$ $0.876, \mathrm{P}=0.349$ ). There were no much difference in the age group as regards their awareness of pest of fruit vegetables. The secondary occupation of the respondents significantly affected their awareness of insect pest problems in fruit vegetable cultivation $\left(\mathrm{x}^{2}=6.473, \mathrm{P}=0.011\right)$ with student more aware of insect pest problems than other categories of the respondents. Secondary students shows higher awareness, others in the group had little perception about insect pest of fruit vegetables. Farmers were asked further about the insect type infesting their crop, namely grasshopper, beetles and moth/caterpillar (Table 4). Age group between 30-39 were able to identify the pest type while majority of farmers above 60 years old showed lower identification.

Table 4. Farmers perception of insect type infesting their fruit vegetables.

\begin{tabular}{|c|c|c|c|c|}
\hline \multirow{2}{*}{ Farmer's category } & \multicolumn{3}{|c|}{ Total respondents } \\
\cline { 2 - 5 } & Grasshopper & Beetles & $\begin{array}{c}\text { Moth } \\
\text { Caterpillar }\end{array}$ & None \\
\hline Age & & & & \\
Below 20 & $4(11.8)$ & $4(33.3)$ & $2(11.1)$ & $2(11.1)$ \\
$20-29$ & $7(20.6)$ & $3(25.0)$ & $1(5.6)$ & $1(5.6)$ \\
$30-39$ & $8(23.5)$ & $4(33.3)$ & $4(5.6)$ & $4(22.2)$ \\
$40-49$ & $7(20.6)$ & $0(0)$ & $4(22.2)$ & $8(44.4)$ \\
$50-59$ & $7(20.6)$ & $1(8.3)$ & $8(4.4)$ & $3(16.7)$ \\
Above 60 & $1(2.9)$ & $0(0)$ & $3(16.7)$ & $0(0)$ \\
Linear by linear association & $0.195(\mathrm{P}=0.659)$ & & & \\
Educational qualification & & & & \\
No formal education & $3(8.8)$ & $2(16.7)$ & $4(4.7)$ & $2(11.1)$ \\
Primary school & $5(14.7)$ & $4(33.3)$ & $10(77.6)$ & $1(5.6)$ \\
Secondary school & $23(67.6)$ & $5(41.7)$ & $66(76.7)$ & $13(72.2)$ \\
Post secondary & $3(25.0)$ & $1(8.3)$ & $6(7.0)$ & $2(11.1)$ \\
Linear by linear association & $0.876(\mathrm{P}=0.349)$ & & & \\
\hline
\end{tabular}




\begin{tabular}{|c|c|c|c|c|}
\hline Secondary occupation & & & & \\
Civil servant & $3(8.8)$ & $1(8.3)$ & $0(0)$ & $0(0)$ \\
Private business & $5(14.7)$ & $2(16.6)$ & $2(11.1)$ & $2(11.1)$ \\
Student & $18(52.9)$ & $5(41.7)$ & $7(38.9)$ & $7(38.9)$ \\
Retiree & $4(11.8)$ & $0(0)$ & $2(11.1)$ & $2(11.1)$ \\
Clergyman & $4(11.8)$ & $4(33)$. & $7(38.9)$ & $7(38.9)$ \\
Linear by linear association & $6.473(\mathrm{P}=0.011)$ & & & \\
\hline
\end{tabular}

\section{4. Farmers' rating of insect pests}

Farmers generally rated insect pests as most serious problem pest because of the pest's significant effect on their crop. $78.4 \%$ of the farmers rated insect pests as the most serious problem because they reduce their vegetable harvest. $52.2 \%$ rated them high because they cause damage to their vegetables and fewer farmers said they increase cost of production while $33.3 \%$ farmers gave all the above mentioned reasons for rating insect pests as a major problem to vegetable production. Neither the age group $\left(\mathrm{x}^{2}=0.023, \mathrm{P} 0.880\right)$ nor the education qualification $\left(\mathrm{x}^{2}=3.115, \mathrm{P}=0.078\right)$ nor secondary occupation $\left(\mathrm{x}^{2}=0.266, \mathrm{P}=\right.$ 0.606) had significant effect on the reasons given by the respondents on their rating of insect pests (Table 5).

Table 5. Farmers reasons for rating insect pest as most serious pest.

\begin{tabular}{|c|c|c|c|c|}
\hline \multirow{2}{*}{ Farmer's category } & \multicolumn{4}{|c|}{ Total respondents } \\
\cline { 2 - 5 } & $\begin{array}{c}\text { They increase } \\
\text { the cost of } \\
\text { production }\end{array}$ & $\begin{array}{c}\text { They reduce } \\
\text { vegetable } \\
\text { harvest }\end{array}$ & $\begin{array}{c}\text { They cause } \\
\text { damage to } \\
\text { vegetable }\end{array}$ & $\begin{array}{c}\text { All of the } \\
\text { above }\end{array}$ \\
\hline Age & & & & \\
\hline Below 20 & $2(18.2)$ & $1(8.3)$ & $12(15.8)$ & $10(19.6)$ \\
$20-29$ & $3(27.3)$ & $4(33.3)$ & $11(14.5)$ & $6(11.8)$ \\
$30-39$ & $3(27.3)$ & $1(8.3)$ & $16(21.1)$ & $17(33.3)$ \\
$40-49$ & $3(27.2)$ & $3(25.0)$ & $21(27.6)$ & $11(21.6)$ \\
$50-59$ & $0(0)$ & $3(25.0)$ & $15(19.7)$ & $7(13.7)$ \\
Above 60 & $0(0)$ & $0(0)$ & $1(1.3)$ & $0(0)$ \\
Linear by linear association & 0.023 & & & \\
Educational qualification & $(\mathrm{P}=0.880)$ & & & \\
No formal education & $3(27.3)$ & $1(8.3)$ & $6(7.9)$ & $1(2.0)$ \\
Primary school & $0(0)$ & $4(33.3)$ & $8(10.5)$ & $8(15.7)$ \\
Secondary school & $7(63.6)$ & $7(58.3)$ & $54(17.1)$ & $39(76.5)$ \\
Post secondary & $1(9.1)$ & $0(0)$ & $8(10.5)$ & $3(5.9)$ \\
Linear by linear association & $(\mathrm{P}=0.078)$ & & & \\
\hline
\end{tabular}




\begin{tabular}{|c|c|c|c|c|}
\hline Secondary occupation & & & & \\
Civil servant & $0(0)$ & $0(0)$ & $2(2.6)$ & $2(3.9)$ \\
Private business & $2(18.2)$ & $4(33.3)$ & $4(5.3)$ & $9(17.6)$ \\
Student & $6(54.5)$ & $5(41.7)$ & $43(56.1)$ & $22(43.1)$ \\
Retiree & $2(18.2)$ & $1(41.7)$ & $22(43.1)$ & $6(11.8)$ \\
Clergyman & $1(9.1)$ & $2(16.7)$ & $9(11.8)$ & $12(23.5)$ \\
Linear by linear association & 0.266 & & & \\
\hline
\end{tabular}

\section{5. Farmer's pest management practices}

Farmers in the surveyed area put considerable effort into fruit vegetable pest management in order to maintain good yields. The farmers used a combination of chemical and cultural method of pest control. The most prevalent cultural method of the pest control in the age category was crop rotation; while $66.7 \%$ of those who used bush clearing were secondary school levers. The students formed the majority $(58.3 \%)$ of those who used shifting cultivation. Those in the 30-39 yrs, (37.1\%), secondary school leavers $(68.6 \%)$ and students $(45.7 \%)$ formed the majority that used chemicals as component of integrated pest management. The survey indicates that farmers were extremely alert to the infestation of insect pest of fruit vegetables. $32 \%$ of the farmers made use of chemical control (Table 6).

Table 6. Method of insect pests control used by the respondents.

\begin{tabular}{|c|c|c|c|c|}
\hline \multirow{2}{*}{ Farmer's category } & \multicolumn{3}{|c|}{ Cultural method } \\
\cline { 2 - 5 } & chemical method & Weeding & $\begin{array}{c}\text { shifting } \\
\text { cultivation }\end{array}$ & $\begin{array}{c}\text { crop } \\
\text { rotation }\end{array}$ \\
\hline Age & & & \\
Below 20 & $6(17.1)$ & $3(14.3)$ & $1(8.3)$ & $15(18.3)$ \\
$20-29$ & $5(14.3)$ & $2(9.5)$ & $2(16.7)$ & $15(18.3)$ \\
$30-39$ & $13(37.1)$ & $3(14.3)$ & $4(33.3)$ & $17(18.3)$ \\
$40-49$ & $9(25.7)$ & $7(33.3)$ & $5(41.7)$ & $17(20.7)$ \\
$50-59$ & $2(5.7)$ & $6(28.6)$ & $0(0)$ & $17(20.7)$ \\
Above 60 & $0(0)$ & $0(0)$ & $0(0)$ & $1(1.2)$ \\
Linear by linear association & $0.113(\mathrm{P}=0.737)$ & & & \\
Educational qualification & & & & \\
No formal education & $4(11.4)$ & $2(9.5)$ & $1(8.3)$ & $3(11.0)$ \\
Primary school & $4(11.4)$ & $3(14.3)$ & $4(33.3)$ & $4(75.6)$ \\
Secondary school & $24(68.6)$ & $14(66.7)$ & $7(58.3)$ & $5(8.5)$ \\
Post secondary & $3(8.6)$ & $2(9.5)$ & $0(0)$ & $6(3.7)$ \\
Linear by linear association & $1.101(\mathrm{P}=0.294)$ & & & $7(14.5)$ \\
\hline
\end{tabular}




\begin{tabular}{|c|c|c|c|c|}
\hline Secondary occupation & & & & \\
Civil servant & $0(0)$ & $1(4.8)$ & $0(0)$ & $3(3.7)$ \\
Private business & $3(8.6)$ & $3(14.3)$ & $1(8.3)$ & $12(14.5)$ \\
Student & $16(45.7)$ & $13(61.9)$ & $7(58.3)$ & $40(48.8)$ \\
Retiree & $4(11.4)$ & $2(9.5)$ & $1(8.3)$ & $8(13.4)$ \\
Clergyman & $12(36.3)$ & $2(9.5)$ & $3(25.0)$ & $16(19.5)$ \\
Linear by linear association & $1.918(\mathrm{P}=0.166)$ & & & \\
\hline
\end{tabular}

\section{DISCUSSION}

Farmers in all the five local government areas surveyed perceived insect pest of fruit vegetables as major pest. Farmers grow vegetables during the wet (in the up-land) and dry season (in the wetlands). They do cultivate fruit vegetables such as tomatoes, peper, okro and garden egg throughout the year in this area. According to farmers perceptions, grasshopper, beetles and moth/ caterpillar are major insect pest of fruit vegetables, this is in agreement with the work of Grzywacz et al. (2010). Moths/caterpillars has been identified as the most damaging pests of fruit vegetables in Africa, the present study confirms this to be the case of Ogbomoso Area. Also in West Africa okro fruit is attacked by flea beetles, Podagrica uniform and $P$. sjostedti which are responsible for heavy defoliation (Odebiyi 1980). In our previous observations grasshoppers especially Zonocerus variegates are known to be polyphagous in the area deverstating dry season vegetable field.

Of the reasons given for cultivation of fruit vegetables student indicated low cost of production because they negative resources as they are dependents who rely on things pertinent for payment of school fees. Another reason given by the correspondent is nearness to market. Therefore in promoting fruit vegetable production among the rural dwellers, marketing outlet should be promoted by governments in order to exchange. Since low cost of production would indirectly imply higher returns any government policy to reduce cost of production and boost fruit vegetable production among the rural farmers.

Farmers are experiencing yield loss, reduced harvest, and increase in cost of production and reduction in market value which lead to reduced income. The majority of the farmers estimated up to $65.4 \%$ loss due to insect pest of fruit vegetables. Farmers have adequate knowledge of insect pest infesting fruit vegetables with most of the farmers being able to recognize fruit fly as insect pest of vegetable. Some perceived that it bore into the fruit, feed on the fruit and fly around the fruit. Also they were able to recognize other part of the fruit vegetable attacked by insect pest which are leaf, stem and root thereby reducing rate of fruit development because these are areas where food are stored. From the result, majority of the farmers do cultivate tomatoes because it is easy to cultivate, easy to market, matures early and cost of production is low.

Pest management practices used by the farmers are cultural and chemical control methods. This shows that the concept of integrated pest management (IPM) was not new to the rural farmers. It was observed that shifting cultivation and crop rotation were practiced by the farmers, while shifting cultivation was possible because of a fertile land tenure system, where in farmers can easily go to another portion of the family land holding. Some of the farmers depend on the use of chemical control, this is in agreement with the reports of the growing dependence on synthetic insecticides for the control of vegetable crop pests reported 
by many authors (Grzywacz et al., 2010; Obopile et al., 2008; Orr and Ritchie, 2004). Most of the pesticides applied are potent toxins and their intensive use poses potential hazards to humans, livestock and the environment (Chambers et al., 2001; Ngowi et al., 2007) with the widespread use of insecticides in Africa, local populations of this pest have started developing resistance to synthetic pyrethroids, organophosphates and carbamates (Kfir 2003). The indiscriminate use of chemical pesticides to achieve higher vegetable yields could lead to disruption of natural control systems, increase the risk of contamination of the farm environment, pesticide residues in fresh produce and health risk to consumers. This highlights the importance of identifying and promoting safer and low alternatives to the synthetic products. Despite the high level of pest awareness, some farmers did not report any specific control measure used. This observation justifies the necessity for the extension agents to reach out to the farmers and educate them on different component of IPM.

It is specifically noted that none of the farmers had an awareness of host plant resistance and biological control. These two strategies could be incorporated into IPM product for the farmers in the studied area. It should be noted that farmer's indigenous management practices of fruit vegetable insect pests should be given due attention in research and development of fruit vegetable insect pest management strategies. Packaging their indigenous knowledge or management practices in an IPM module will encourage their adaptation of such modules. This will eventually lead to reduced production costs and increases financial gain for the resource poor rural fruit vegetable producers.

\section{References}

[1] Abate T.A., van Huis, J.K.O., Annual Review of Entomology 45 (2000) 631-659.

[2] Ampofo, J.K.O., (1997) Utilizing host plant resistance in integrated pest management (IPM) systems for the small-scale farmer in Africa. Integrating biological control and host plant resistance.In: Proceedings of a CTA/IAR/IIBC seminar, 9-14 October 1995, CTA, Addis Ababa. The Neitherlands, pp. 38-45.

[3] Chamber H.W., Boone Z.S., Carr R.L., Chanbers J.E. (2001): Chemistry of organophosphorus insecticides. In: Robert I.K. (ed) Handbook of Pesticides Toxicology, Academics press, CA, pp. 913-917.

[4] Gabriel T., Tropical Pest management 35(3) (1989) 254-256.

[5] Grzywacz D., Rossbach A., Rauf A., Russell D.A., Srini vasan R., Sheiton A.M., Crop Protection 29 (2010) 68-79.

[6] Kfir R. (2003). Biological control of the diamond Plutella Xylostella in Africa. In Neuenschwander P, Borgameister C, Langewald J (eds) Biological control in IPM systems in Africa, CAB international Wallingford, pp. 363-375.

[7] Ngowi A.V.F, Mbise T.J, Ijani A.S.M, London L., AJayi O.C., Crop Protection 26 (2007) 1617-1624.

[8] Nyeko P., Edwards J. G., Day R.K., Raussen T., Crop Prot. 21 (2002) 929-941.

[9] Obopile M, Munthali D.C, Matiloo B., Crop Protection 27(8) (2008) 1220-1224.

[10] Odebiyi J.A., African Journal of Agricultural Science 6 (1980) 83-84.

[11] Ojo D.O., Olufolaji A.O., Gartenbauwissenschaft 41 (1997) 280-28. 
[12] Orr A, Ritchie J.M., Agricutural System 79 (2004) 31-54.

[13] Shamser S., Verma V.S., Journal of vegetable, Environment and Ecology 14 (4) (1996) 834-836.

[14] Tefera T., International Journal Pest management 50 (2004) 35-40.

( Received 24 August 2014; accepted 31 August 2014 ) 